\title{
Cadmium Removal from Giant Squid (Dosidicus gigas) Hydrolysate in Fixed-Bed Columns Packed with Iminodiacetic Resin: Tools for Scaling up the Process
}

\author{
Carolina Calderón ${ }^{1,2}$ (D), Marcela Levío-Raimán ${ }^{1,2}$ (D) and M. Cristina Diez ${ }^{2,3, * \mathbb{D}}$ \\ 1 Doctoral Program in Sciences of Natural Resources, University of La Frontera, Temuco 4780000, Chile; \\ carolina.calderon@ufrontera.cl (C.C.); marcela.levio@ufrontera.cl (M.L.-R.) \\ 2 Biotechnological Research Center Applied to the Environment (CIBAMA-BIOREN), University of La Frontera, \\ Temuco 4780000, Chile \\ 3 Chemical Engineering Department, University of La Frontera, Temuco 4780000, Chile \\ * Correspondence: cristina.diez@ufrontera.cl
}

check for updates

Citation: Calderón, C. Levío-Raimán, M.; Diez, M.C. Cadmium Removal from Giant Squid (Dosidicus gigas) Hydrolysate in Fixed-Bed Columns Packed with Iminodiacetic Resin: Tools for Scaling up the Process. Int. J. Environ. Res. Public Health 2022, 19, 442. https:// doi.org/10.3390/ijerph19010442

Academic Editors: Joanna Łuczyńska, Marek Jan Łuczyński,

Magdalena Senze,

Monika Kowalska-Góralska and Mu Naushad

Received: 29 October 2021

Accepted: 27 December 2021

Published: 31 December 2021

Publisher's Note: MDPI stays neutral with regard to jurisdictional claims in published maps and institutional affiliations.

Copyright: (c) 2021 by the authors Licensee MDPI, Basel, Switzerland. This article is an open access article distributed under the terms and conditions of the Creative Commons Attribution (CC BY) license (https:// creativecommons.org/licenses/by/ $4.0 /)$.

\begin{abstract}
Giant squid hydrolysate (GSH) elaborated from different batches from a fishing company was evaluated for cadmium removal. Fixed-bed column packed with iminodiacetic resin as adsorbent was used. GSH solution at different cadmium concentrations were fed in the fixed-bed column and breakthrough curves were evaluated. A high degree of metal removal from the solution was achieved and the saturation point $\left(\mathrm{C}_{\mathrm{e}} / \mathrm{C}_{0} \leq 0.8\right)$ was achieved more quickly at higher concentrations of cadmium. The maximum capacity of adsorption $\left(\mathrm{q}_{0}\right)$ was obtained using the Thomas model, where 1137.4, 860.4, 557.4, and $203.1 \mathrm{mg} \mathrm{g}^{-1}$ were achieved using GSH with concentrations of 48.37, 20.97, 12.13 , and $3.26 \mathrm{mg} \mathrm{L}^{-1}$, respectively. Five cycles of desorption of the resin with $\mathrm{HCl}(1 \mathrm{M})$ backflow and regeneration with $\mathrm{NaOH}(0.5 \mathrm{M})$ were also evaluated, where no significant differences ( $p$-value $>0.05$ ) were observed between each cycle, with an average of $935.9 \mathrm{mg} \mathrm{g}^{-1}$ of $\mathrm{q}_{\max }$. The in-series columns evaluated reached a total efficiency of $90 \%$ on average after the third column in GSH with a cadmium concentration of $20.97 \mathrm{mg} \mathrm{L}^{-1}$. This kind of configuration should be considered the best alternative for cadmium removal from GSH. Additionally, the chemical composition of GSH, which was considered a quality parameter, was not affected by cadmium adsorption.
\end{abstract}

Keywords: cadmium removal; iminodiacetic resin; hydrolysate protein; fixed-bed column; Thomas model

\section{Introduction}

The giant squid (Dosidicus gigas) represents the most important squid fishery species in the world, accounting for 15\% of global volumes from the total capture of mollusks [1] Mollusks, such as giant squid, can be affected by absorbing and accumulating cadmium in their tissues and digestive glandules. They can assimilate more than $50 \%$ of metals present in water in a particulate or dissolved form [2]. High cadmium content has been found in the digestive glands (levels from 57 to $509 \mathrm{mg} \mathrm{kg}^{-1}$ of dry weight) and gills (levels from 6.5 to $17 \mathrm{mg} \mathrm{kg}^{-1}$ of dry weight) [3] of these animals.

Giant squid is of increasing economic interest in many countries, such as Chile, Peru, China, Mexico, and Japan, due to its high-value proteins and lipids. However, during its processing, up to $40 \%$ of this mollusk's body weight is wasted in the form of by-products, including heads, viscera, backbones, ink, skin, fins, arms, tentacles, and unclaimed mantle. All these by-products can be turned into protein hydrolysates due to their high levels of protein, low molecular weight, high digestibility, high water holding capacity, and highwater solubility. This can be used to enhance animal nutrition (piglets, poultry, aquaculture, pet food).

As mentioned above, added-value products elaborated from giant squid by-products are contaminated with high levels of cadmium [3,4], causing a high level of risk for their consumers. 
Cadmium is found in GSH as a free ion $\left(\mathrm{Cd}^{2+}\right)$ or as an ionic complex associated with other organic and inorganic substances, such as metallothionein protein. This is a low-molecular-weight protein that is responsible for capturing and mobilizing cadmium within organs, such as the liver and kidneys [5].

In this context, the adsorption process has been widely studied and is reported to be a highly efficient and eco-friendly method for heavy metal removal. Resins are one of the most well-known adsorbents for cadmium removal. Resins are mainly composed of synthetic polymers functionalized with organic compounds that can exchange their mobile ions for ions of similar charge from the surrounding medium [6]. Despite resins being used primarily for cadmium removal from wastewater [7,8], they have also been used to remove cadmium from food, such as squid sauce [4] and squid liver [9].

The main advantages of the adsorption process are the reusability, low operating costs, improved selectivity for the specific metals of interest, short operation time, and the lack of production of secondary compounds [10].

As an effective alternative, iminodiacetic resin for cadmium removal from giant squid hydrolysate was demonstrated by Calderón et al. [11], which was the first approach in this field that addressed and proposed solutions for food application. A batch assay comparison between a standard solution of cadmium and GSH samples revealed high variations in adsorption of cadmium, which was influenced highly by the complexity of the matrix. In this sense, is important to improve the adsorption process used to test continuous systems. Additionally, fixed-bed columns were reported as more advantageous than the batch method because of their simplicity of operation, faster adsorption time, and easy scale-up process from the lab [11,12].

The purpose of this study was to evaluate the use of fixed-bed columns for the removal of cadmium from a giant squid hydrolysate (GSH) using iminodiacetic resin as an adsorbent that does not affect the nutritional components of this product in order to improve the scalability of the process.

\section{Materials and Methods}

\subsection{Adsorbent}

A commercial resin provided by Dimerco ${ }^{\circledR}$ was used for cadmium removal. This resin is a macroporous styrene-divinylbenzene polymeric matrix with donor atoms that can form chelate complexes with metallic ions, the functional group of which is based on iminodiacetic acid (Figure 1). The resin has a specific surface BET of $21.5 \mathrm{~m}^{2} \mathrm{~g}^{-1}$, a pore volume of $0.036 \mathrm{cc} \mathrm{g}^{-1}$, a pore diameter of $1.04 \mathrm{~nm}$ (obtained by Calderon et al. [11]), and a total exchange capacity of $30 \mathrm{~g}$ of cations $\mathrm{L}^{-1}$.

a)<smiles>[R]CN(CC(=O)O[Na])CC(=O)O[Na]</smiles>

b)<smiles>[R]CN(C[R])CC(=O)O</smiles>

Figure 1. Iminodiacetic acid is the functional group of resin and the mechanism of chelating of cadmium by the (a) $\mathrm{Na}$ form and (b) $\mathrm{H}$ form. 


\subsection{Giant Squid Hydrolysate}

Giant squid hydrolysate (GSH) is a liquid product that contains soluble proteins, a lipidic fraction, and suspended solids corresponding to the non-hydrolyzed fraction. Giant squid hydrolysate (GSH) was obtained via an enzymatic hydrolysis process using giant squid by-products and was elaborated in a seafood plant processing located in the BíoBío region of Chile at a real scale ( $2500 \mathrm{~kg}$ per batch). The giant squid by-product consisted mainly of a mix of muscle tissue (mantle, tentacles, fins, and skin) and digestive glands. Considering that high cadmium content was found in digestive glands, four GSH batches were prepared with different proportions of digestive glands, as shown in Table 1. Giant squid by-products were ground and hydrolyzed using an enzymatic method (commercial protease, with a dosage of $0.01 \%$ of the total protein content) for $1 \mathrm{~h}$ while stirring ( $200 \mathrm{rpm}$ ) at $50{ }^{\circ} \mathrm{C}$. Subsequently, the soluble fraction was sieved in order to remove the solids from the cartilage and bones, heated for pasteurization, and then centrifugated to remove the major fat contents. After each GSH batch, samples were taken for the cadmium removal assays. For GSH characterization, after each batch, samples of GSH were dried in a spray dryer (Niro Mod. Mobile Minor ${ }^{\mathrm{TM}}$ ).

Table 1. Batches of giant squid hydrolysate (GSH) elaborated with different proportions of digestive glands at different production dates (weekly during May) and the resulting concentration of cadmium and $\mathrm{pH}$ of each batch.

\begin{tabular}{cccc}
\hline Batch $^{\circ}$ & $\begin{array}{c}\text { Digestive Glands } \\
(\mathbf{\%})\end{array}$ & $\begin{array}{c}\text { Cadmium Concentration } \\
\left(\mathbf{m g ~ L}^{-\mathbf{1}}\right)\end{array}$ & pH \\
\hline 1 & 70 & 48.27 & 6.16 \\
2 & 40 & 20.97 & 6.20 \\
3 & 20 & 12.13 & 6.15 \\
4 & 5 & 3.26 & 6.11 \\
\hline
\end{tabular}

\subsection{Column Design at Lab Scale}

In order to make the cadmium adsorption representative of the industrial process of GSH production, a reference flowrate of $2.8 \mathrm{~m}^{3} \mathrm{~h}^{-1}$ was considered for the column design on the lab scale. The following variables were considered for the column design: linear velocity, space velocity, and expansion of the resin pack.

Linear velocity, defined by the path of the fluid through the transversal section of the column per unit of time [13], is represented in Equation (1):

$$
\mathrm{LV}=\frac{Q}{A}
$$

where $Q$ is the flow rate $\left(\mathrm{cm}^{3} \mathrm{~s}^{-1}\right) ; A$ is an area of a cross-section $\left(\mathrm{cm}^{2}\right)$, and $\mathrm{LV}$ is the linear velocity $\left(\mathrm{cm} \mathrm{s}^{-1}\right)$.

Space velocity is frequently used in ion exchange and adsorption operations in fixed beds and is frequently called "relative volumetric flow rate" $\left(Q_{r e l}\right)$. The most common unit of $\mathrm{Q}_{\text {rel }}$ is bed volumes per hour (BV/h) [13], described in Equation (2):

$$
\mathrm{EV}=\frac{Q}{V_{r}}
$$

where $Q$ is the flow rate $\left(\mathrm{cm}^{3} \mathrm{~s}^{-1}\right)$ and $V_{r}$ corresponds to the volume of the adsorbent $\left(\mathrm{cm}^{3}\right)$.

In order to facilitate the backwash operation described in Section 2.4, it was necessary to calculate the expansion percentage of the adsorbent into the column. The supplier of the resin recommended an expansion of $50-75 \%$. The expansion is represented by Equation (3):

$$
\mathrm{E}(\%)=\left(\frac{H-h}{h}\right) \times 100
$$


where $H$ is the height of the column $(\mathrm{cm}), h$ is the height of the resin $(\mathrm{cm})$, and $E$ corresponds to the expansion (\%).

All these variables were put into an objective function using SOLVER ${ }^{\circledR}$ in Microsoft Excel in order to check their compliance with all the restrictions and optimize the column operation service. The resulting column had a length of $70 \mathrm{~cm}$, an internal diameter of $2.5 \mathrm{~cm}, 140 \mathrm{~g}$ of iminodiacetic resin, a linear velocity of $0.475 \mathrm{~cm} \mathrm{~s}^{-1}$, a space velocity of $0.012 \mathrm{~s}^{-1}$, and a $71.5 \%$ expansion rate (Figure 2).

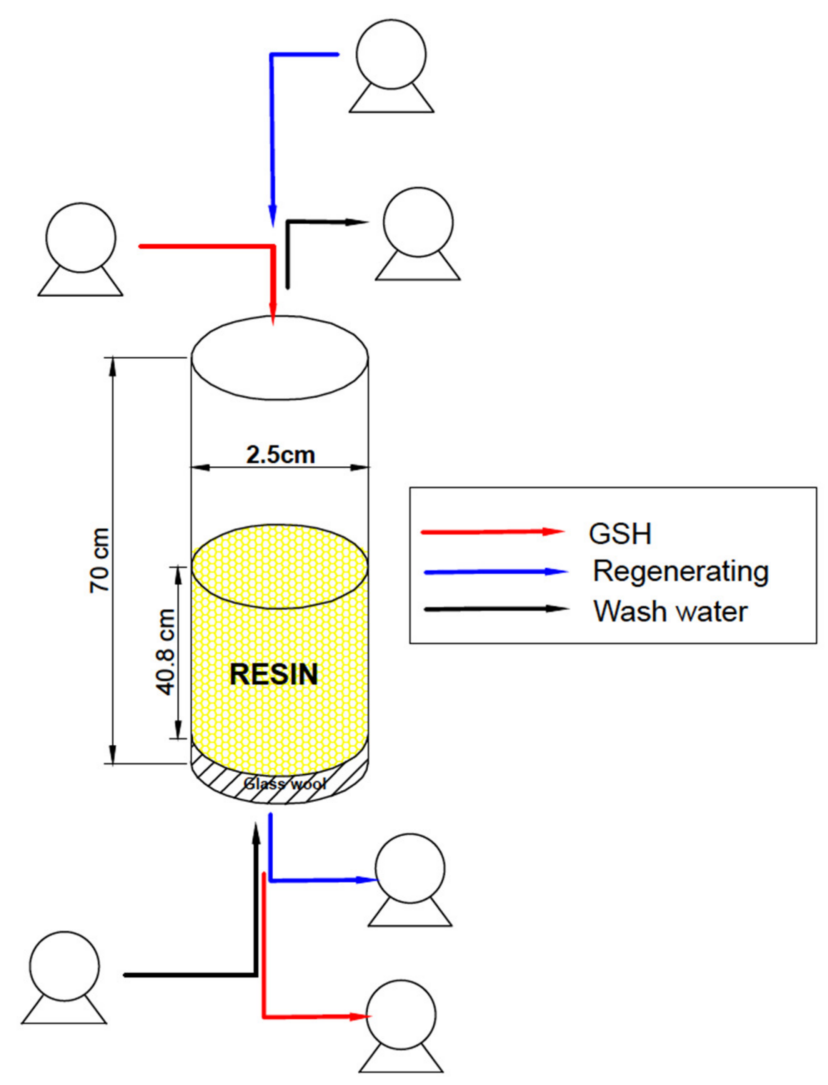

Figure 2. Column designed with a length of $70 \mathrm{~cm}$ and an internal diameter of $2.5 \mathrm{~cm}$ packed with $140 \mathrm{~g}$ of iminodiacetic resin equivalent to a volume of $200 \mathrm{cc}$. A $71.5 \%$ of expansion rate was considered.

\subsubsection{Operation of the Fixed-Bed Column}

Stainless steel columns, the dimensions of which were obtained from Section $2.3(70 \mathrm{~cm}$ length and $2.5 \mathrm{~cm}$ internal diameter), were packed with $140 \mathrm{~g}$ of iminodiacetic resin $(200 \mathrm{cc})$ and operated in a continuous system. Before eluting the GSH, the columns packed with iminodiacetic resin were preconditioned with water at $55{ }^{\circ} \mathrm{C}$ for $10 \mathrm{~min}$. Liquid GSH at $55 \pm 2{ }^{\circ} \mathrm{C}$ and $\mathrm{pH} 6.2$ with different cadmium concentrations according to each batch described in Table 1 was pumped from the top of the column at a flow rate of $0.14 \mathrm{~L} \mathrm{~min}^{-1}$ using a peristaltic pump. At the outlet of the column, the treated GSH sample was collected at regular time intervals. The experimental conditions that influenced the adsorption of cadmium in the fixed-bed column were evaluated using breakthrough curves. The saturation point was determined using $C_{e} / C_{0} \geq 0.8$, where $C_{e}$ and $C_{0}\left(\mathrm{mg} \mathrm{L}^{-1}\right)$ are the cadmium concentrations in the effluent and influent, respectively. The evaluation of the column performance was conducted by plotting the relation between the cadmium concentration in the effluent with the cadmium concentration in the influent $\left(C_{e} / C_{0}\right)$ as a function of time (minutes). The cadmium concentration was measured using an atomic absorption spectrophotometer (AAS). All experiments were carried out in triplicate. Additionally, the 
total adsorption capacity of the column $\left(\mathrm{q}_{\text {total }}\right)$ at a given $\mathrm{pH}$, inlet concentration, and flow rate was evaluated experimentally and was calculated using Equation (4):

$$
\mathrm{q}_{\mathrm{total}}=\int_{t=0}^{t=\text { total }}\left(C_{0}-C_{t}\right) d t
$$

\subsubsection{Modeling of Cadmium Adsorption in the Fixed-Bed Column}

The experimentally obtained breakthrough curves were fitted using the Thomas model [14] to calculate the adsorption rate and solid-phase concentration of cadmium from continuous mode studies. The nonlinear form of the Thomas model can be expressed as described below in Equation (5):

$$
\frac{C_{e}}{C_{0}}=\frac{1}{1+\exp \left[\frac{K_{T h} \cdot\left(q_{0} \cdot m-C_{0} \cdot V\right)}{\mathrm{F}}\right]}
$$

The linearized form of the Thomas model can be expressed as follows in Equation (6):

$$
\ln \left(\frac{C_{0}}{C_{e}}-1\right)=\frac{K_{T h} \cdot q_{0} \cdot m}{\mathrm{~F}}-K_{T h} \cdot C_{0} \cdot t
$$

where $C_{e}$ is the outlet cadmium concentration $\left(\mathrm{mg} \mathrm{L}^{-1}\right), C_{0}$ is the initial cadmium concentration in the influent $\left(\mathrm{mg} \mathrm{L}^{-1}\right), K_{T h}$ is the Thomas model rate constant $\left(\mathrm{mL} \mathrm{min} \mathrm{mg}^{-1}\right)$, $q_{0}$ is the equilibrium cadmium from GSH adsorbed per gram of resin $\left(\mathrm{mg} \mathrm{g}^{-1}\right), m$ is the mass of adsorbent $(\mathrm{g}), V$ is the effluent volume $(\mathrm{mL})$, and $\mathrm{F}$ is the flow rate $\left(\mathrm{mL} \mathrm{min}^{-1}\right)$. The constants $K_{t}$ and $q_{0}$ were determined from the linear form of the Thomas model (Equation (6)).

\subsection{Column Desorption, Regeneration, and Reusability Assay}

For the cadmium desorption study, the column for cadmium adsorption of GSH from batch 2 (20.97 $\mathrm{mg} \mathrm{L}^{-1}$ ) was used due to this cadmium concentration being more frequently found in by-products of giant squid. As an elution reagent, $\mathrm{HCl}(1 \mathrm{M})$ was used and fed into the backflow at a flow rate of $0.1 \mathrm{~L} \mathrm{~min}^{-1}$. The eluted solution was collected at regular time intervals for $30 \mathrm{~min}$ and the cadmium content was measured using AAS. After the desorption step, $\mathrm{NaOH}$ was used for resin regeneration via conversion to the $\mathrm{Na}^{+}$form by eluting $\mathrm{NaOH} 0.5 \mathrm{M}$ at a flow rate of $0.5 \mathrm{~L} \mathrm{~min}^{-1}$ for $20 \mathrm{~min}$. Subsequently, the column was washed thoroughly using deionized water and reused for each cycle of cadmium adsorption.

The sequence of desorption-regeneration followed by a wash was considered one cycle. The evaluation of the adsorbent reusability was conducted after five repeated cycles. The saturation points and desorption curves of each cycle were evaluated using the relation $\mathrm{Ce} / \mathrm{C}_{0}$ as a function of time ( $\left.\mathrm{min}\right)$. Additionally, each cycle was evaluated using the Thomas model and the total capacity of cadmium adsorption was determined as described in Sections 2.3.1 and 2.3.2.

\subsection{In-Series Columns System Evaluation}

Stainless steel columns prepared and operated as described in Section 2.3.1 were disposed in series, and liquid GSH from batch $2\left(20.97 \mathrm{mg} \mathrm{L}^{-1}\right)$ was added at the top of the first column, which then feed the subsequent columns. Each column was operated for $60 \mathrm{~min}$. The cadmium concentration at the end of the first column was considered the initial concentration of the next column. Cadmium removal (\%) was calculated using Equation (7), where $C_{0}$ is the initial concentration and $C_{T}$ is the cadmium concentration after the third column operation:

$$
\text { Cadmium removal }(\%)=\left(\frac{C_{0}-C_{T}}{C_{0}}\right) \cdot 100
$$


The characterization of GSH samples before and after cadmium removal in fixed-bed columns disposed of in series was made. Before the analyses, samples were spray dried and the results are expressed as the dry weight. The chemical composition, mineral profile, and aminoacidic composition of GSH before and after the in-series adsorption process using iminodiacetic resin were determined (Section 2.7).

\subsection{Statistical Analysis}

Statistical significance was assessed using one-way ANOVA with Tukey's test using the software package SPSS/PCTM version 22.0 (SPSS Inc., Chicago, IL, USA). The $p$-values less than 0.05 were considered statistically significant.

\subsection{GSH Characterization}

GSH was analyzed using the following methodologies: moisture (ISO 6496/1999), protein (AOAC Method 984.13, 1994), fat (AOAC Method 920.39, 1920), total ashes (ISO 5984:2002), and pepsin digestibility (AOAC Method 971.09). The mineral profile was determined using an atomic absorption spectrophotometer (AAS) (Perkin-Elmer model PinAAcle 900-H) and plasma emission spectroscopy (inductively coupled plasma (ICP)). The aminoacidic profile was analyzed using HPLC (626 LC System, Column (AccQ-Tag)) and a UV-visible detector. Moreover, before and after saturation of the columns with a GSH solution, the iminodiacetic resin packed in a bed column was dried at $60{ }^{\circ} \mathrm{C}$ for $24 \mathrm{~h}$ and used for resin observation using scanning electronic microscopy (SEM) (Model SU-3500 Hitachi, Tokyo, Japan).

\section{Results and Discussion}

\subsection{Breakthrough Curves}

The cadmium concentrations in the GSH varied according to the proportion of raw material (giant squid by-product), where the amount (\%) of digestive glands had a relevant influence on the content of cadmium during the process (Table 1), with a correlation coefficient $\left(\mathrm{R}^{2}\right)$ of 0.975 . Figure 3 a displays the breakthrough curves constructed at different cadmium concentrations present in the GSH. The adsorption breakthrough curves showed two clearly differentiated phases. As the concentration of cadmium in the GSH increased, the column saturated more quickly. The earliest breakthrough point at a higher cadmium content in the GSH ( $48.37 \mathrm{mg} \mathrm{L}^{-1}$ ) was observed at $45 \mathrm{~min}$. The binding sites became more quickly saturated in the column and this indicated that an increase in the cadmium GSH inlet concentration could modify the adsorption rate through the bed [14]. On the other hand, when the cadmium content in the GSH was the lowest $\left(3.26 \mathrm{mg} \mathrm{L}^{-1}\right)$, the column saturation was three times slower (135 $\mathrm{min})$.

In this context, Nazari et al. [15] observed that a high concentration gradient can increase the intensity of transport inside the pores (i.e., diffusion coefficient), thereby accelerating the adsorption process and saturation. A gradual saturation of binding sites was also observed by Sasaki et al. [4], where the cadmium concentration of a fish sauce increased linearly with elution volume passed through a resin with ethylenediamine as the functional group.

\subsection{Thomas Modeling in Columns Assays}

The experimental adsorption breakthrough curves for cadmium were constructed and compared using the breakthrough curves predicted according to the Thomas model, as represented by Figure $3 a$ by dotted lines. Figure $3 b$ presents the linearization of the Thomas model and the experimental data, where high correlation coefficients $\left(\mathrm{R}^{2}\right)$ were obtained with values of $0.972,0.977,0.979$, and 0.908 for $48.37,20.97,12.13$, and $3.26 \mathrm{mg} \mathrm{L}^{-1}$ cadmium concentrations in the GSH, respectively (Table 2). Table 2 provides the Thomas model parameters and a comparison of the quantity adsorbed (experimental and theoretical) at different initial concentrations of cadmium in GSH solutions. In general, the maximum experimental adsorption of cadmium $\left(\mathrm{q}_{\text {total }}\right)$ was similar to the predicted maxi- 
mum adsorption of cadmium $\left(q_{\max }\right)$ by the model, where the highest value of cadmium adsorbed onto the resin was for an initial concentration of $48.37 \mathrm{mg} \mathrm{L}^{-1}$ of cadmium in the GSH solution, with a $\mathrm{q}_{\text {total }}$ of $1015.3 \mathrm{mg} \mathrm{g}^{-1}$ and $\mathrm{q}_{\max }$ of $1137.4 \mathrm{mg} \mathrm{g}^{-1}$, thus demonstrating a major affinity of the resin for cadmium at elevated cadmium concentrations in the GSH.
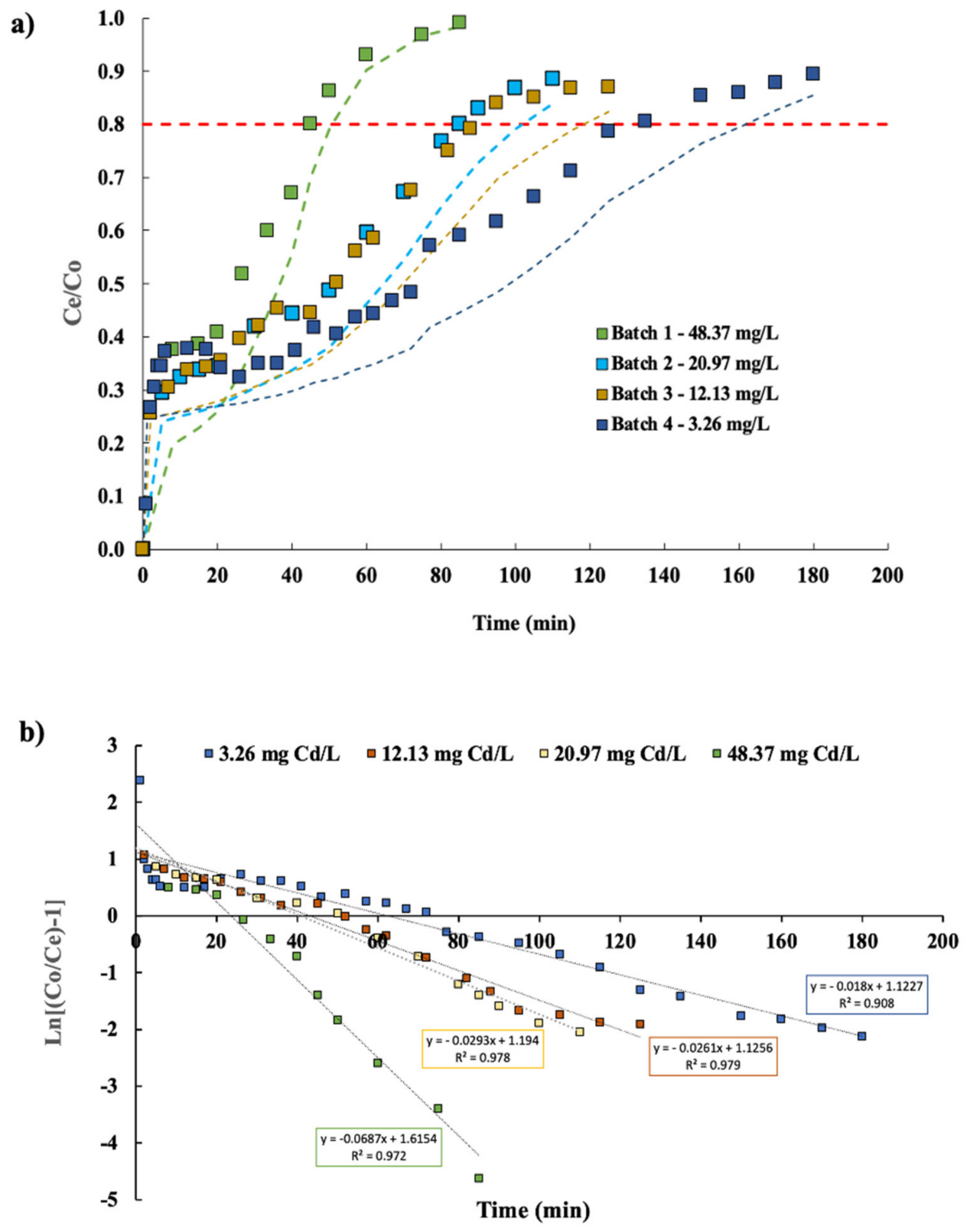

Figure 3. (a) Effect of the influent concentration on the breakthrough curves for cadmium adsorption by a fixed-bed column packed with resin as an adsorbent until saturation $\left(\mathrm{C} / \mathrm{C}_{0}<0.8\right)$. The symbols represent the experimental data and the dotted line represents the data fitted to the Thomas model. (b) Linearized representation of the Thomas model at the different initial concentrations of cadmium in the GSH solutions represented by the GSH solution with $3.26 \mathrm{mg} \mathrm{L}^{-1}, 12.13 \mathrm{mg} \mathrm{L}^{-1}, 20.97 \mathrm{mg} \mathrm{L}^{-1}$, and $48.37 \mathrm{mg} \mathrm{L}^{-1}$ cadmium concentrations. Both representations were performed with a flow rate of $0.14 \mathrm{~L} \mathrm{~min}^{-1}$, $\mathrm{pH}$ of 6.2 , adsorbent mass of $140 \mathrm{~g}$, and operating temperature of $55^{\circ} \mathrm{C}$. 
Table 2. The Thomas model parameters in a fixed-bed column packed with iminodiacetic resin that were found at different initial concentrations of cadmium in the GSH solution. The experimental conditions were a $\mathrm{pH}$ of 6.2 , a flow rate of $140 \mathrm{~mL} \mathrm{~min}^{-1}$, and a temperature of $55^{\circ} \mathrm{C}$.

\begin{tabular}{|c|c|c|c|c|}
\hline $\begin{array}{l}\text { Initial Cd Concentration } \\
\left(\mathrm{mg} \mathrm{L}^{-1}\right)\end{array}$ & $\underset{\left(\mathrm{mg} \mathrm{g}^{-1}\right)}{\mathrm{q}_{\max }}$ & $\begin{array}{c}\mathrm{K}_{\mathrm{T}} \\
\left(\mathrm{mL} \mathrm{min}^{-1} \mathrm{mg}^{-1}\right)\end{array}$ & $\mathbf{R}^{2}$ & $\begin{array}{c}\mathrm{q}_{\text {total }} \\
\left(\mathrm{mg} \mathrm{g}^{-1}\right)\end{array}$ \\
\hline 48.37 & 1137.4 & 0.0014 & 0.972 & 1015.3 \\
\hline 20.97 & 860.4 & 0.0014 & 0.978 & 827.1 \\
\hline 12.13 & 557.4 & 0.0020 & 0.979 & 519.8 \\
\hline 3.26 & 203.1 & 0.0055 & 0.908 & 200.3 \\
\hline
\end{tabular}

With respect to the adsorption capacity, Sasaki et al. [4] obtained an estimated value of maximum capacity of $0.3 \mathrm{mg} \mathrm{g}^{-1}$ for a fish sauce with a cadmium concentration of $300 \mathrm{mg} \mathrm{L}^{-1}$ and a flow rate of $5 \mathrm{~mL} \mathrm{~h}^{-1}$ with chelate resin as the adsorbent according to their experimental results. Xiong and Yao [6] achieved a maximum capacity of $349 \mathrm{mg} \mathrm{g}^{-1}$; however, different conditions of cadmium concentration $\left(200 \mathrm{mg} \mathrm{L}^{-1}\right)$, influent flow rate, and type of eluted sample were used.

Regarding the Thomas rate constant $\left(\mathrm{K}_{\mathrm{T}}\right)$ shown in Table 2, an inverse relation between the cadmium concentration in the GSH and the rate constant $\left(\mathrm{K}_{\mathrm{T}}\right)$ was observed. Values of $\mathrm{K}_{\mathrm{T}}$ were 0.0014 and $0.0055 \mathrm{~L} \mathrm{~min} \mathrm{mg}^{-1}$ for 48.37 and $3.26 \mathrm{mg} \mathrm{L}^{-1}$, respectively. The same value of $\mathrm{K}_{\mathrm{T}}$ of the GSH with a cadmium concentration of $48.37 \mathrm{mg} \mathrm{L}^{-1}$ and $20.97 \mathrm{mg} \mathrm{L}^{-1}$ was obtained. Thus, as the cadmium concentration increased, the $\mathrm{K}_{\mathrm{T}}$ value decreased, which means that the resistance to the mass transference of the pollutant into the resin was decreased. This enhanced the adsorption capacity of the resin and, therefore, favored the intra-particular diffusion from the solution up to the solute. At the same time, the opposite effect was observed at lower cadmium concentrations in the GSH solution, which reduces the adsorption capacity $\left(q_{0}\right)$ of the resin and increased its resistance to the mass transference of cations.

\subsection{Desorption and Reusability System}

The regeneration of the adsorbents is one of the key factors used to assess their potential utilization in industrial scale applications, which would save operation costs for a removal system.

The desorption system was evaluated in order to test the reusability of the resin. In this context, $\mathrm{HCl}(1 \mathrm{M})$ allowed for the removal of the cadmium chelated to the surface of the resin and was effective as a desorption agent after saturation (Figure 4a).

Cadmium desorption from a saturated column with the GSH solution at $20.97 \mathrm{mg} \mathrm{L}^{-1}$ was achieved after $18 \mathrm{~min}$, removing $97 \%$ of the cadmium adsorbed in the resin. These results were corroborated by Saleh et al. [16] with a desorption efficiency between $92-100 \%$ using $\mathrm{HCl}$ at $0.3 \mathrm{M}$ for cadmium adsorbed by a chelate resin. Additionally, and according to previous assays, better efficiency of desorption and subsequent saturation was achieved when the resin was converted to the Na form. Similarly, Taha et al. [17] achieved the best desorption efficiency with $\mathrm{HCl}$ and $\mathrm{H}_{2} \mathrm{SO}_{4}(1 \mathrm{M})$ as desorption agents, showing $98.9 \%$ and $100 \%$ cadmium removal, respectively, from saturated sulfonic and amino-phosphonic resins.

On the other hand, similar breakthrough points $\left(C_{e} / C_{0}=0.8\right)$ were observed in each cycle after the desorption and regeneration process (Figure $4 \mathrm{~b}$ ). Saturation was achieved at similar times $(100 \mathrm{~min})$ and no significant differences $(p$-value $>0.05)$ were observed between each cycle of saturation-desorption-regeneration. The resin was able to remove cadmium from the GSH solution, desorbing the cadmium and regenerating correctly in five consecutive cycles. 


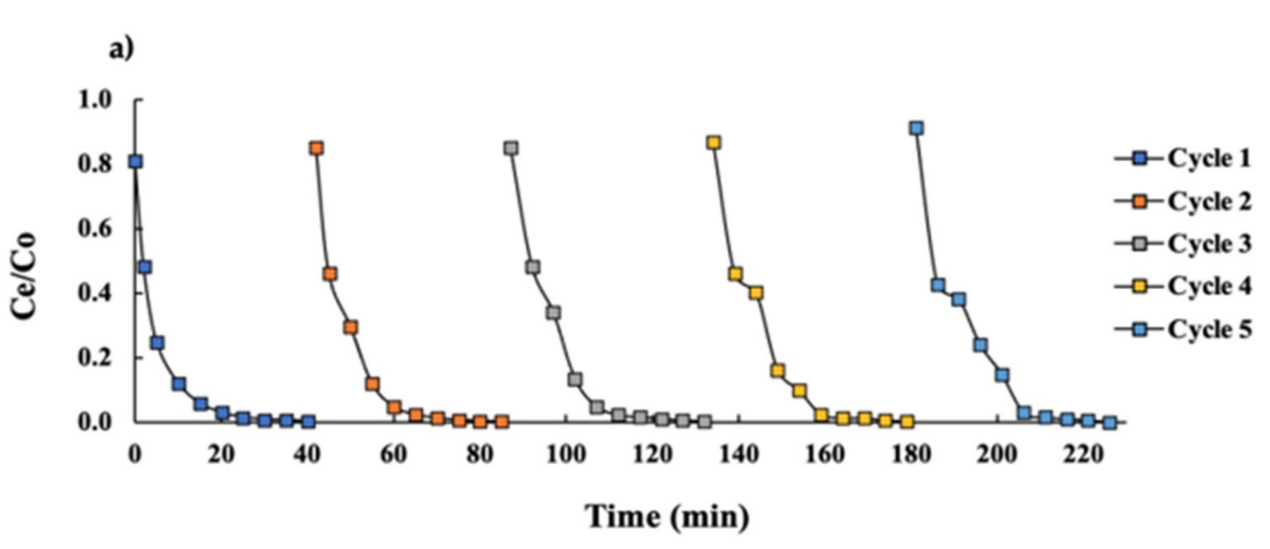

b)

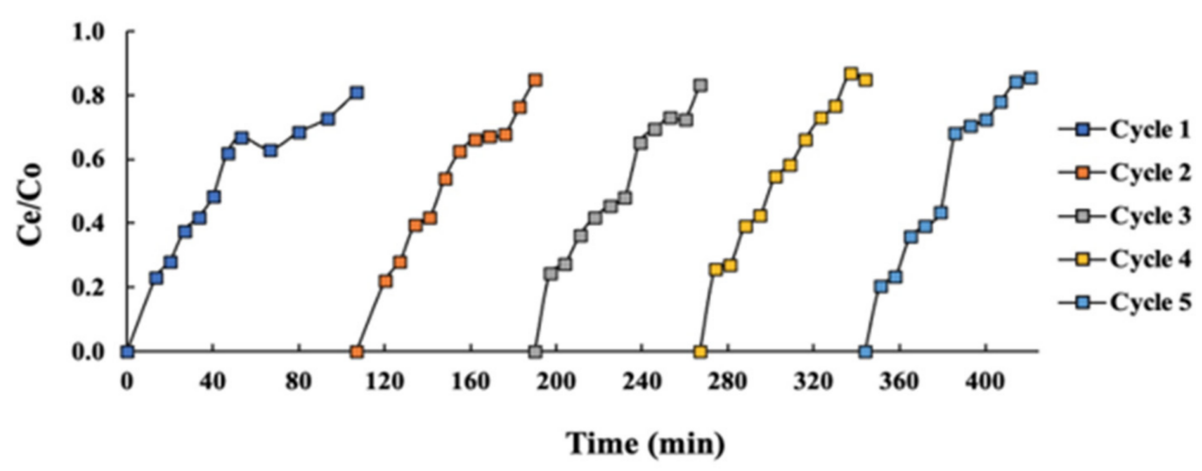

Figure 4. Sequences of cadmium desorption-regeneration-conversion-washing of the saturated column with the GSH solution at a $20.97 \mathrm{mg} \mathrm{L}^{-1}$ cadmium concentration, $\mathrm{pH}$ of 6.2 , and temperature of $55 \pm 2{ }^{\circ} \mathrm{C}$. A backwash solution as a desorption agent was added at a flow rate of $0.1 \mathrm{~L} \mathrm{~min}^{-1}$. (a) Desorption of the cadmium process represented by 5 cycles. (b) Cycles of saturation of resin by cadmium from GSH.

The adsorption capacity $\left(q_{0}\right)$ was evaluated in each cycle, where no significant differences were observed $(p>0.05)$. Moreover, an average $q_{\max }$ value of $945 \mathrm{mg} \mathrm{g}^{-1}$ between the five cycles was obtained. In terms of the loss in the adsorption capacity of the resin for cadmium removal, no losses were detected after each cycle. This might be due to the unremarkable mass of adsorbent lost during the adsorption-desorption process. These results indicated that the iminodiacetic resin packed in a fixed-bed column offers the potential to be used repeatedly in cadmium adsorption studies without any detectable loss in the total adsorption capacity over five consecutive cycles. It should be noted that there have been no reusability studies performed with iminodiacetic resin removing cadmium from this type of matrix (GSH).

\subsection{In-Series Columns System Evaluation}

Three columns connected in series were packed with resin and the cadmium removal from the GSH solution at $20.97 \mathrm{mg} \mathrm{L}^{-1}$ of cadmium was evaluated and is shown in Figure 5. After the first column operated for $60 \mathrm{~min}$, the cadmium concentration decreased from 20.97 to $9.0 \mathrm{mg} \mathrm{L}^{-1}$, followed by the second column with a decrease from 9.0 to $4.8 \mathrm{mg} \mathrm{L}^{-1}$ and a decrease of cadmium concentration of GSH after the third column from 4.8 to $2.1 \mathrm{mg} \mathrm{L}^{-1}$ (Figure 5)). Regarding the total removal, the three columns reduced the cadmium concentration of the GSH from $20.97 \mathrm{mg} \mathrm{L}^{-1}$ to $2.10 \mathrm{mg} \mathrm{L}^{-1}$. In this sense, the three steps resulted in a better cadmium removal system than one, with a total removal of $90 \%$. Accordingly, triple the resin in one column could be used as another alternative. In this regard, resins allowed for the removal of higher volumes of the pollutant and may be reused several times. Otherwise, the first column favors the cadmium removal, where the cadmium con- 
centration fed in the column was higher. This can be explained by changes in the surface adsorption properties during the binding of ions on the inner and outer surfaces, which is more intensive at higher initial concentrations [18]. Speciation of the metal at pH 6.2 also favors cadmium entrapment by the $2 \mathrm{Na}^{+}$present in the resin structure (iminodiacetic acid).

(a)
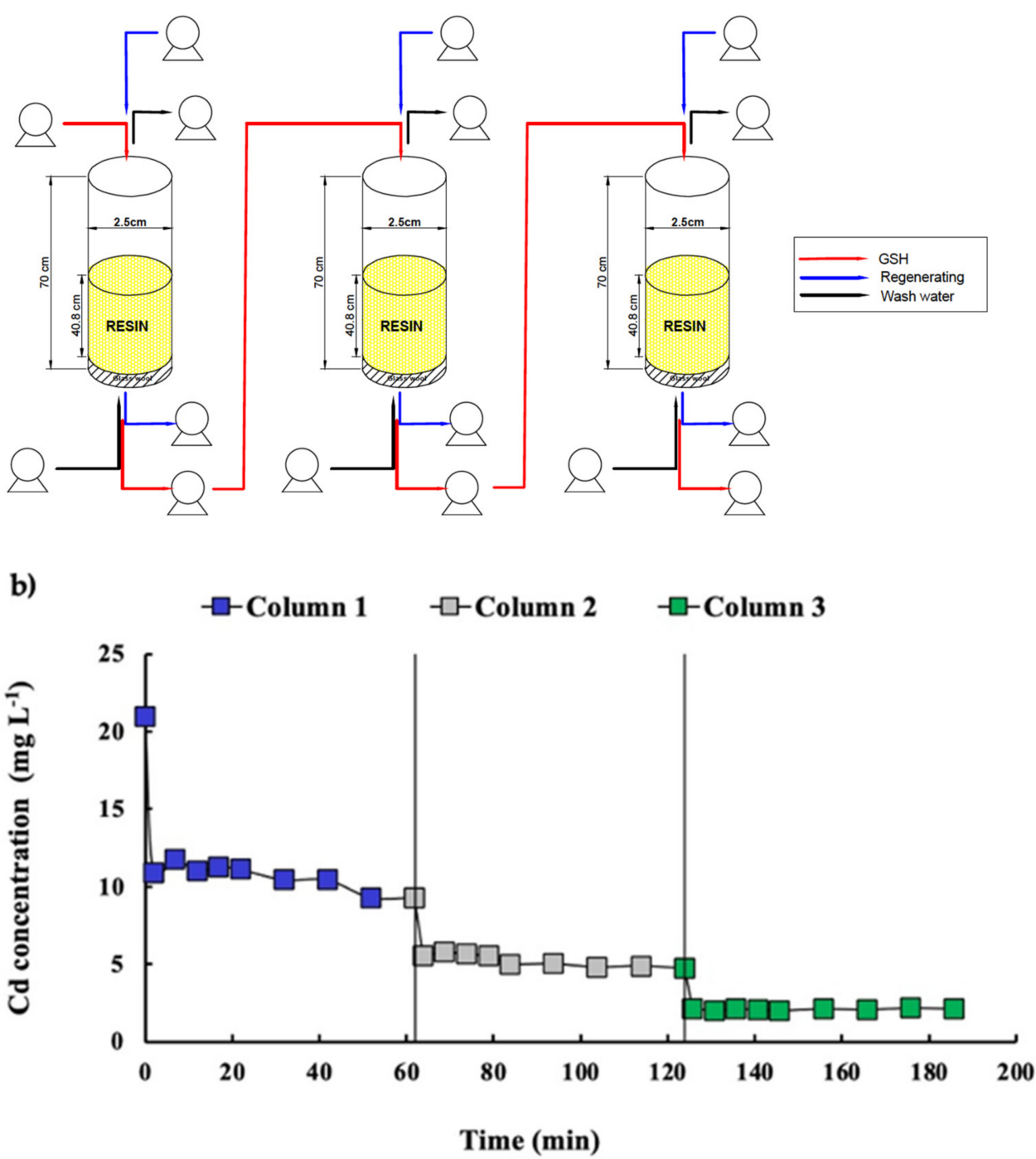

Figure 5. (a) Schematic representation of the three columns connected in series. (b) cadmium concentration performed in the column assay connected in series. The initial cadmium concentration in column 1 was $20.97 \mathrm{mg} \mathrm{L}^{-1}$. The final concentration of one column was the inlet concentration of the next column. The final concentration was $2.10 \mathrm{mg} \mathrm{L}^{-1}$.

On the other hand, results of $98 \%$ and $99 \%$ cadmium removal were obtained by Elbadawy et al. [19] from a standard solution, where the column method was considered more efficient and economical than the batch process for practical applications. However, high cadmium removal was achieved using an ideal matrix (standard cadmium solution) and lower flow rate conditions with a standard cadmium solution of $18.24 \mathrm{mg} \mathrm{L}^{-1}$ and $1.5 \mathrm{~mL} \mathrm{~min}^{-1}$, respectively.

\subsection{GSH Characterization}

The chemical characterization of the liquid GSH samples from batch 2, which was obtained after the centrifugation step, before and after the adsorption in fixed-bed columns 
is shown in Table 3. The total protein content, soluble protein, and digestibility did not change significantly $(p>0.05)$ due to the total adsorption process. The main difference between the before and after the total adsorption process was related to the fat $(23 \%)$ and salt $(5.5 \%)$ contents $(p<0.05)$. The fat retained on the resin surface acted as a waterproofing agent, where it was able to block the surface and the active sites of the resin. In fact, the polymeric matrix of the resin (styrene-divinylbenzene) is able to capture lipophilic compounds and this resin is generally used as a package of chromatographic columns for the retention of antibiotics, toxins, etc.

Table 3. Characterization (\%) of the GSH sample from batch $2\left(20.97 \mathrm{mg} \mathrm{L}^{-1}\right)$ before and after the cadmium adsorption in fixed-bed columns connected in series. The experimental conditions were a $\mathrm{pH}$ of 6.2 , a flow rate of $140 \mathrm{~mL} \mathrm{~min}{ }^{-1}$, and a temperature of $55^{\circ} \mathrm{C}$. The results are expressed as the dry weight and are the average of three repetitions.

\begin{tabular}{|c|c|c|}
\hline Parameter & $\begin{array}{l}\text { GSH before Adsorption } \\
\text { (\% d.w) }\end{array}$ & $\begin{array}{c}\text { GSH after Adsorption } \\
(\% \text { d.w })\end{array}$ \\
\hline Protein & $83.9 \pm 0.9 \mathrm{a}$ & $86.3 \pm 0.9 \mathrm{a}$ \\
\hline Fat & $7.8 \pm 0.6 b$ & $5.9 \pm 0.1 b$ \\
\hline Ash & $8.0 \pm 0.4 \mathrm{a}$ & $7.6 \pm 0.1 \mathrm{a}$ \\
\hline Salt (NaCl) & $4.8 \pm 0.2 \mathrm{ab}$ & $3.9 \pm 0.1 \mathrm{ab}$ \\
\hline Soluble protein & $63.5 \pm 2.5 a$ & $62.6 \pm 0.5 a$ \\
\hline Digestibility (pepsin) & $99.9 \pm 0.0 \mathrm{a}$ & $99.9 \pm 0.0 \mathrm{a}$ \\
\hline
\end{tabular}

The average values and the standard error are presented $(n=3)$. Different letters refer to the significant differences $(p<0.05$, Tukey's test) of the mean values of each parameter before and after the cadmium removal.

On the other hand, solids also blocked the binding sites and could form a kind of fouling on the saturated resin. Figure 6 shows the SEM images captured before and after the adsorption process. Before the adsorption process, a spherically shaped resin with an average diameter of $560 \mu \mathrm{m}$, a uniform morphology, and a smooth surface was observed (Figure 6a). After the total adsorption process, the resin was coated with a film consisting of white spots, which was attributable to the presence of inorganic material, and a layer of lipid material on the surface of the resin (Figure 6b). Calderon et al. [11] showed that in a batch study, $44.9 \%$ of the fat content from GSH remained in resin after an adsorption treatment, meaning losses on the adsorption capacity of the resin and a faster resin saturation. In contrast, the use of adsorption fixed-bed columns connected in series allowed us to treat the GSH more efficiently despite the lipid layer coating the resin. In this regard, the presence of undesirable compounds in the adsorption process for cadmium removal, such as other metals, salts, and fat content, interfered with and blocked the binding sites of the resin.

Table 4 shows the mineral profile of the liquid GSH before and after the adsorption process in the fixed-bed columns connected in series. We can observe that the GSH had high sodium (Na) content (>16,000 $\mathrm{mg} \mathrm{kg}^{-1}$ ) followed by magnesium (Mg) and calcium (Ca) $\left(>600 \mathrm{mg} \mathrm{kg}^{-1}\right)$. Cadmium and copper $(\mathrm{Cu})$ were present in the GSH at concentrations of $138.8 \mathrm{mg} \mathrm{kg}^{-1}$ and $219 \mathrm{mg} \mathrm{kg}^{-1}$, respectively, and zinc $(\mathrm{Zn})$ and iron (Fe) were present at concentrations of less than $80 \mathrm{mg} \mathrm{kg}^{-1}$. Sodium was predominantly present as $\mathrm{NaCl}$ in the GSH due to the marine habitat of the species. After the total adsorption process, a high degree of cadmium removal was obtained (90\%), followed by $\mathrm{Fe}, \mathrm{Cu}$, and $\mathrm{Na}(>81 \%)$. To a lesser extent, $\mathrm{Zn}$ and $\mathrm{Mg}$ were removed (78.63 and 68.4\%, respectively), followed by $\mathrm{Ca}$ removal $(34.28 \%$ ) (Table 4$)$. In our study, no competition between cadmium and the other metals was observed, in contrast to data reported by other authors [7,20,21], who evidenced competition for the active sites of adsorbents. According to the technical specifications of the commercial iminodiacetic resin, it is particularly suitable for the removal of heavy metals (as weakly acidic chelated complexes), which are held according to the following order of selectivity: $\mathrm{Cu}>>\mathrm{Ni}>\mathrm{Zn} \geq \mathrm{Co} \geq \mathrm{Cd}>\mathrm{Fe}(\mathrm{II})>\mathrm{Mn}>\mathrm{Ca}$. In our study, the adsorption sequence was as follows: $\mathrm{Cd}>>\mathrm{Cu}>\mathrm{Na}>\mathrm{Fe}>\mathrm{Zn}>\mathrm{Mg}>\mathrm{Ca}$. The greater cadmium adsorption compared to copper and other metals can be explained by the $\mathrm{pH}$ 
of the GSH (6.2), which favors cadmium adsorption, which, according to the speciation, copper requires acidic conditions ( $\mathrm{pH} 2-5)$ to be removed easily. Moreover, the result suggests that cadmium could be released from $\mathrm{Cd}-$ metallothionein $(\mathrm{Cd}-\mathrm{MT})$ during the enzymatic hydrolysis process to obtain the GSH, where protein is fractioned to achieve peptides with lower molecular weight, which could facilitate greater adsorption onto the resin than other metals. Despite the high level of monovalent element $(\mathrm{Na})$ present in the GSH, no inhibition of cadmium adsorption onto the resin by $\mathrm{Na}$ was observed. This is consistent with the study performed by Sasaki et al. [4], where they demonstrated that cadmium may bind iminodiacetic acids more strongly than $\mathrm{Na}$, reflecting differences in the binding modes and spatial structures.
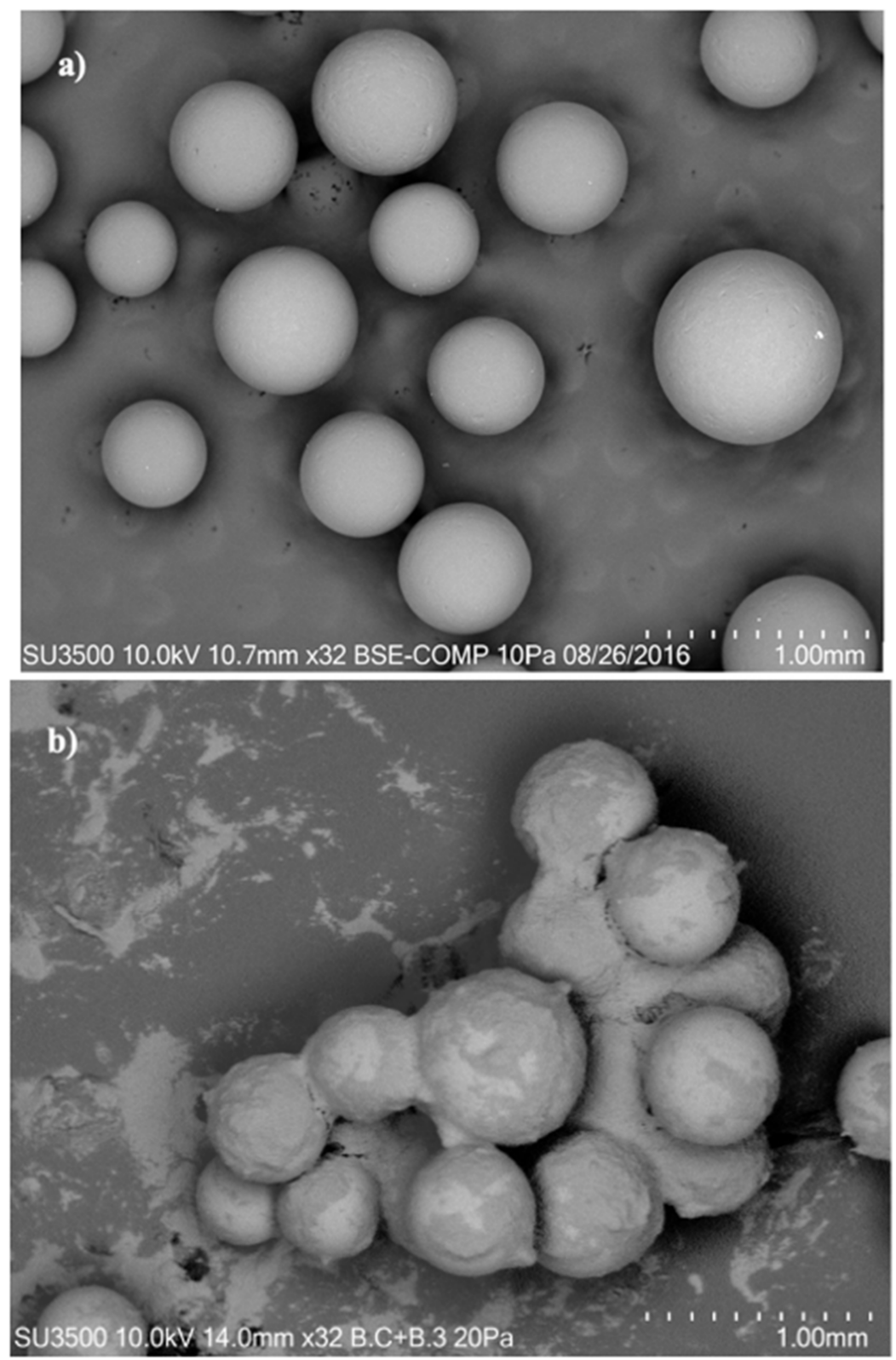

Figure 6. Scanning electronic microscopy (SEM) images of the resin before and after the cadmium adsorption from the GSH solution. (a) Resin in the original state and (b) resin from a saturated column. The cadmium concentration of the liquid GSH was $20.97 \mathrm{mg} \mathrm{L}^{-1}$. 
Table 4. The mineral profile ( $\left.\mathrm{mg} \mathrm{kg}^{-1}\right)$ of GSH samples from batch $2\left(20.97 \mathrm{mg} \mathrm{L}^{-1}\right)$ before and after the cadmium adsorption in fixed-bed columns connected in series. The experimental conditions were a pH of 6.2 , a flow rate of $140 \mathrm{~mL} \mathrm{~min}-1$, and a temperature of $55^{\circ} \mathrm{C}$. The results are expressed as the dry weight and are the average of three repetitions.

\begin{tabular}{|c|c|c|c|}
\hline Metal & $\begin{array}{l}\text { GSH before Adsorption } \\
\left(\mathrm{mg} \mathrm{kg}^{-1}\right)\end{array}$ & $\begin{array}{l}\text { GSH after Adsorption } \\
\left(\mathrm{mg} \mathrm{kg}^{-1}\right)\end{array}$ & $\begin{array}{c}\text { Removal } \\
(\%)\end{array}$ \\
\hline Cadmium (Cd) & $139 \pm 3.8$ & $14 \pm 0.4$ & 90.0 \\
\hline Calcium (Ca) & $643 \pm 5.3$ & $368 \pm 17.7$ & 34.3 \\
\hline Magnesium (Mg) & $600 \pm 15.9$ & $190 \pm 22.5$ & 68.4 \\
\hline Iron $(\mathrm{Fe})$ & $40 \pm 1.5$ & $9 \pm 0.3$ & 81.9 \\
\hline Copper $(\mathrm{Cu})$ & $219 \pm 8.0$ & $23 \pm 0.5$ & 89.7 \\
\hline Zinc (Zn) & $77 \pm 2.8$ & $15 \pm 0.8$ & 78.6 \\
\hline Sodium (Na) & $16,000 \pm 870.0$ & $12,900 \pm 451.5$ & 19.4 \\
\hline
\end{tabular}

Regarding the nutritional or antinutritional properties of GSH as an ingredient intended for animal consumption, the elimination of other metals, such as copper, is beneficial. Copper is classified by the Association of Food Control Officials of the United States (AFFCO) as toxic, where levels between 10-40 ppm in a complete diet and levels between 100-1000 ppm are suggested for food ingredients. Low levels of toxic elements reinforce the idea of commercializing safe food. In contrast, elements such as zinc have an average requirement in diets of $50-100 \mathrm{ppm}$ (depending on the species). In this sense, the decrease in this metal due to the effect of cadmium removal could imply that the formulator must supplement the deficiency. It should be noted that the addition of these protein hydrolysates such as GSH in diets does not exceed 5\%; therefore, the contribution of contaminants and essential minerals will not be significant in the complete formulation.

Cadmium adsorption from the GSH placed onto fixed-bed columns connected in series using the iminodiacetic resin as an adsorbent did not greatly affect the content of the GSH amino acids (Table 5). On the other hand, the amino acid content did not interfere with the cadmium adsorption process. A similar result was reported by Sasaki et al. [4] where the total free amino acids did not influence cadmium removal in a squid sauce using iminodiacetic resin. Moreover, we did not observe important interference by amino acids as part of metallothionein (MT). MT possesses a highly conserved amino acid sequence that is mainly composed of up to 20 cysteine (Cys) residues [22] and metal-rich proteins containing sulfur-based metal clusters formed with $\mathrm{Zn}^{2+}, \mathrm{Cd}^{2+}$, and $\mathrm{Cu}^{2+}$ ions. In the case of GSH, predominant amino acids, such as histidine, arginine, and lysine (Table 5), have basic R groups. Therefore, they tend to bind protons, gaining a positive charge in the process, where the protonated forms predominate at physiological $\mathrm{pH}$ (about 7). Thus, the $\mathrm{pH}$ of GSH (6.2) also favors some competition for the cadmium binding between amino acids and resin.

\subsection{Mass Balance and Analysis Data for Simulation}

The design of cadmium removal columns for scaling up to an industrial scale involves several restrictions for the process to achieve the maximum cadmium removal. The columns connected in series removed $90 \%$ of cadmium from the GSH with a cadmium concentration of $20.97 \mathrm{mg} \mathrm{L}^{-1}$. This result, along with those obtained from the Thomas model for the maximum adsorption capacity $\left(q_{0}\right)$ and others provided by the industry, were used for a general prospecting of a technology on an industrial scale. In this sense, a simulation of a series of three columns was carried out on an industrial scale, feeding the columns connected in series with GSH at $2.8 \mathrm{~m}^{3} \mathrm{~h}^{-1}$ in order to observe the removal capacity of cadmium per unit of time. The amount of cadmium to be treated as waste from the process and the level of exhaustion of the resin are shown in Table 6. 
Table 5. Aminoacidic composition $\left(\mathrm{g}(100 \mathrm{~g})^{-1}\right)$ of the GSH sample from batch $2\left(20.97 \mathrm{mg} \mathrm{L}^{-1}\right)$ before and after the cadmium adsorption in fixed-bed columns connected in series. The experimental conditions were a $\mathrm{pH}$ of 6.2 , a flow rate of $140 \mathrm{~mL} \mathrm{~min}^{-1}$, and a temperature of $55^{\circ} \mathrm{C}$. The results are expressed as the dry weight and are the average of three repetitions.

\begin{tabular}{|c|c|c|}
\hline Aminoacidic Composition & $\begin{array}{l}\text { GSH before Adsorption } \\
\left(\mathrm{g}(100 \mathrm{~g})^{-1}\right)\end{array}$ & $\begin{array}{l}\text { GSH after Adsorption } \\
\left(\mathrm{g}(100 \mathrm{~g})^{-1}\right)\end{array}$ \\
\hline Aspartic acid & $3.13 \pm 0.130 \mathrm{a}$ & $3.09 \pm 0.121 \mathrm{a}$ \\
\hline Serine & $8.03 \pm 0.310 \mathrm{~b}$ & $5.59 \pm 0.123 b$ \\
\hline Glutamic acid & $12.23 \pm 0.220 \mathrm{a}$ & $10.32 \pm 0.187 \mathrm{a}$ \\
\hline Glycine & $0.23 \pm 0.010 \mathrm{a}$ & $0.38 \pm 0.009 \mathrm{a}$ \\
\hline Histidine & $9.86 \pm 0.150 b$ & $12.35 \pm 0.121 b$ \\
\hline Arginine & $8.68 \pm 0.230 \mathrm{a}$ & $8.31 \pm 0.121 \mathrm{a}$ \\
\hline Threonine & $2.48 \pm 0.080 \mathrm{~b}$ & $1.98 \pm 0.021 b$ \\
\hline Alanine & $3.42 \pm 0.070 \mathrm{~b}$ & $2.71 \pm 0.052 b$ \\
\hline Proline & $2.72 \pm 0.050 \mathrm{a}$ & $2.23 \pm 0.041 \mathrm{a}$ \\
\hline Cysteine & $0.12 \pm 0.003 \mathrm{a}$ & $0.13 \pm 0.002 \mathrm{a}$ \\
\hline Tyrosine & $1.77 \pm 0.020 \mathrm{a}$ & $2.10 \pm 0.027 \mathrm{a}$ \\
\hline Valine & $2.71 \pm 0.031 \mathrm{a}$ & $2.16 \pm 0.028 \mathrm{a}$ \\
\hline Methionine & $1.38 \pm 0.040 \mathrm{a}$ & $1.42 \pm 0.029 \mathrm{a}$ \\
\hline Lysine & $4.39 \pm 0.081 \mathrm{~b}$ & $3.06 \pm 0.072 b$ \\
\hline Isoleucine & $2.42 \pm 0.056 \mathrm{a}$ & $1.87 \pm 0.034 \mathrm{a}$ \\
\hline Leucine & $5.37 \pm 0.123 b$ & $3.48 \pm 0.071 \mathrm{~b}$ \\
\hline Phenylalanine & $2.40 \pm 0.054 \mathrm{a}$ & $1.60 \pm 0.036 \mathrm{a}$ \\
\hline
\end{tabular}

The average values and the standard errors are presented $(n=3)$. Different letters refer to significant differences $(p<0.05$, Tukey's test) of the mean values of each amino acid before and after the cadmium removal.

Table 6. Data analysis of cadmium removal using 3 columns connected in series for scaling up a real process. A cadmium concentration in the GSH of $20.97 \mathrm{mg} \cdot \mathrm{L}^{-1}$ and a flow rate of $2800 \mathrm{~L} \mathrm{~h}^{-1}$ (average from the fishing plant) were used.

\begin{tabular}{|c|c|c|}
\hline Parameter & Value & Unit \\
\hline \multicolumn{3}{|l|}{ Data for calculations } \\
\hline Resin packaged per column & 140 & $\mathrm{~kg}$ \\
\hline $\mathrm{N}^{\circ}$ of columns & 3 & $\mathrm{~kg}$ \\
\hline Total resin & 420 & $\mathrm{~kg}$ \\
\hline Flow rate $\left(^{*}\right)$ & 2800 & $\mathrm{Lh}^{-1}$ \\
\hline Total solids of liquid of GSH $\left({ }^{*}\right)$ & 15.0 & $\%$ \\
\hline Cd initial concentration (w.w) & 21.0 & $\mathrm{mg} \mathrm{L}^{-1}$ \\
\hline In series total Cd removal $\left.{ }^{* *}\right)$ & 90 & $\%$ \\
\hline Final conc. of Cd (w.w) $\left.{ }^{* *}\right)$ & 2.1 & $\mathrm{mg} \mathrm{L}^{-1}$ \\
\hline Density of liquid GSH $\left(^{*}\right)$ & 1.1 & $\mathrm{~g} \mathrm{~mL}^{-1}$ \\
\hline Total solids of dried GSH $\left({ }^{*}\right)$ & 95 & $\%$ \\
\hline Cation exchange capacity of resin $\left.{ }^{* * *}\right)$ & 30 & g cation $\mathrm{L}^{-1}$ \\
\hline \multicolumn{3}{|l|}{ Parameter calculated } \\
\hline Cd final concentration $(\mathrm{d} . \mathrm{w})$ & 13.9 & $\mathrm{mg} \mathrm{kg}^{-1}$ \\
\hline Cd final conc. in powder ( $5 \%$ of moisture) & 13.3 & $\mathrm{mg} \mathrm{kg}^{-1}$ \\
\hline Mass of $\mathrm{Cd}$ inlet & $58,716.0$ & $\mathrm{mgCd} \mathrm{h}^{-1}$ \\
\hline Mass of Cd removed by the resin & $52,844.4$ & $\mathrm{mg} \mathrm{Cd} \mathrm{h}^{-1}$ \\
\hline Mass of Cd outlet the column & 5871.6 & $\mathrm{mg} \mathrm{Cd} \mathrm{h}^{-1}$ \\
\hline Level of resin exhaustion by $\mathrm{Cd}$ & 0.589 & $\%$ \\
\hline
\end{tabular}

Following the removal of $90 \%$ of cadmium from liquid GSH, a GSH with a cadmium concentration of $13.8 \mathrm{mg} \mathrm{kg}^{-1}$ (d.w) was obtained. In this regard, cadmium was not removed enough to comply with European regulations, where Directive 2002/32/EC establishes a maximum concentration of $2 \mathrm{mg} \mathrm{kg}^{-1}$ adjusted to a moisture content of $12 \%$ for feed ingredients. However, according to AFFCO's official guidelines for contaminants 
in individual food ingredients, the suggested cadmium levels are between 5 and $500 \mathrm{ppm}$. As an example, if GSH is included as 5\% of the diet, with $13 \mathrm{ppm}$ of cadmium it would contribute $0.7 \mathrm{ppm}$ of cadmium in the diet versus $7.0 \mathrm{ppm}$ without any treatment for cadmium removal. In this sense, the decrease in cadmium levels will be beneficial by providing a competitive advantage relative to other products.

Figure 7 shows that the effluent after the treatment had a mass of cadmium of $5871.6 \mathrm{mg} \mathrm{h}^{-1}$ and that it retained $52,844.4 \mathrm{mg} \mathrm{h}^{-1}$ of the total resin (420 $\mathrm{kg}$ for the three columns).

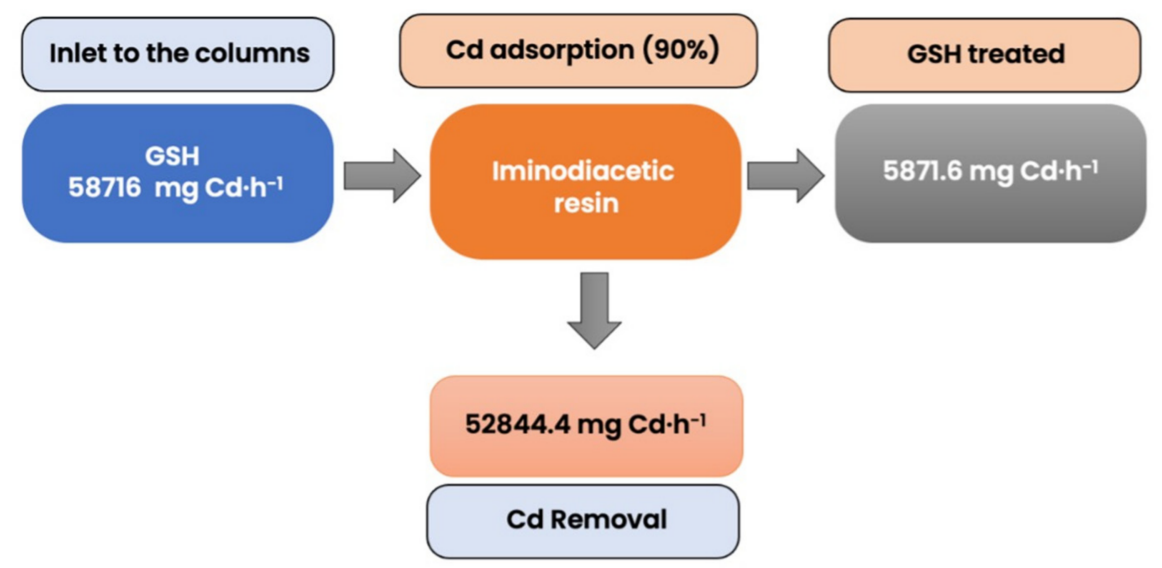

Figure 7. Representation of the mass balance of cadmium removal from GSH by columns in series with $90 \%$ cadmium removal at an industrial scale. The simulation consisted of GSH with a Cadmium concentration at the inlet of $20.97 \mathrm{mg} \mathrm{L}^{-1}, \mathrm{pH}$ of 6.20 , a flow rate of GSH of $2800 \mathrm{~L} \mathrm{~h}^{-1}$, and a resin content of $140 \mathrm{~kg}$ per column.

The process described in this paper generated waste effluents in the form of the $\mathrm{HCl}$ and $\mathrm{NaOH}$ washing solutions, which were contaminated with cadmium, as well as lipids, proteins, and other heavy metals. Therefore, additional treatment for the removal of cadmium, as well as the other impurities, should be considered for the wastewater of food processing plants, which will use the GSH treatment described here. In this sense, cadmium removal from wastewater has hardly been studied, and the most common technology for wastewater purification has been coagulation and flocculation, followed by sedimentation and filtration. These are also used to remove heavy metals from aqueous solutions, where coagulation destabilizes colloids by neutralizing the forces that keep cadmium apart. On the other hand, a low-cost alternative was proposed by Levío-Raiman et al. [23], where an organic biomixture packed in columns was considered a good alternative to remove metal ions.

Level of exhaustion resulted by the relation of the mass of cadmium removed by the resin used by $20 \mathrm{~h}$ per day and the cation exchange capacity provided by the resin supplier. In this context, the level of cadmium exhaustion in the resin reached $0.589 \%$. On the other hand, 142 days would be necessary to saturate the column only with cadmium. This could be attributed to the presence of other metals, proteins, amino acids, and lipids due to the complexity of the GSH, which interferes with the cadmium adsorption by the resin. Physical blockage instead of chemical exhaustion via any excess of cations was observed. Another reason for the low capacity (as compared with the maximum possible cadmium sorption capacity) was the use of the columns in series, where the saturation was undesirable in order to keep the adsorption in equilibrium during the $60 \mathrm{~min}$ of operation.

\section{Conclusions}

In this study, we found that the cadmium concentration in the GSH was dependent on the amount of digestive glands as raw material and the feasibility of iminodiacetic resin for cadmium removal from GSH in continuous conditions using fixed-bed columns. Better removal was obtained with high cadmium concentrations in the GSH. Regarding the cadmium capacity of adsorption, the total capacity obtained $\left(\mathrm{q}_{\text {total }}\right)$ from experimental 
data was similar to that predicted by the Thomas model $\left(q_{\max }\right)$, where all the batches at different concentrations of cadmium were fitted to the model proposed $\left(R^{2}>0.90\right)$.

Desorption-regeneration and reusability studies demonstrated its effectiveness, where acid wash desorption $(\mathrm{HCl})$ and regeneration with $\mathrm{NaOH}$ allowed the spent material to be reused for five consecutive cycles with no significant loss in performance.

More contact time and mass of resin into the column were needed to increase the cadmium removal. Accordingly, the study of the columns connected in series exhibited a total efficiency of $90 \%$ after the third column. This kind of configuration could be considered the best alternative for cadmium removal from GSH.

On the other hand, comparative chemical characterization of GSH before and after cadmium adsorption could confirm a high affinity for cadmium removal over copper and other metals. Additionally, the column saturation could be explained by a physical blockage with the removal of lipids from the GSH acting as a waterproofing agent. This was confirmed by a calculation of the level of cadmium exhaustion, where $0.589 \%$ was the obtained result.

Despite the high level of cadmium removal, it was not possible to achieve a concentration below the maximum for feed ingredients as regulated by the European Union (DIRECTIVE 2002/32/EC), which is $2 \mathrm{mg} \mathrm{kg}^{-1}$ for ingredients elaborated from squid, adjusted to a moisture level of $12 \%$. Thus, the content of cadmium needs to be further managed in GSH elaboration by the standardization of the content of digestive glands, increasing the number of columns, or studying a semicontinuous method (batch columns).

The information generated in this study allows for the implementation and/or adoption of technology suitable for the food and feed industry.

Author Contributions: Conceptualization, C.C., M.L.-R. and M.C.D.; methodology, C.C., M.L.-R., and M.C.D.; software, C.C. and M.L.-R.; validation, M.C.D.; formal analysis, C.C. and M.L.-R.; investigation, C.C.; resources, C.C. and M.C.D.; data curation, C.C. and M.L.-R.; writing-original draft preparation, C.C.; writing-review and editing, C.C., M.L.-R. and M.C.D.; visualization, C.C., M.L-R. and M.C.D.; supervision, M.C.D.; project administration, C.C. and M.C.D.; funding acquisition, C.C. and M.C.D. All authors have read and agreed to the published version of the manuscript.

Funding: This research was funded by ANID/FONDAP/15130015, DIUFRO GAP DI18, ANID Scholarship N²1140220, CORFO PI-1642 and Sociedad Pesquera Landes S.A-Chile.

Conflicts of Interest: The authors declare that there is no conflict of interest.

\section{References}

1. FAO. The State of World Fisheries and Aquaculture 2020; FAO: Rome, Italy, 2020; ISBN 978-92-5-132692-3.

2. Wang, W.X.; Fisher, N.S. Accumulation of trace elements in a marine copepod. Limnol. Oceanogr. 1998, 43, 273-283. [CrossRef]

3. Raimundo, J.; Vale, C.; Rosa, R. Trace element concentrations in the top predator jumbo squid (Dosidicus gigas) from the Gulf of California. Ecotoxicol. Environ. Saf. 2014, 102, 179-186. [CrossRef]

4. Sasaki, T.; Araki, R.; Michihata, T.; Kozawa, M.; Tokuda, K.; Koyanagi, T.; Enomoto, T. Removal of cadmium from fish sauce using chelate resin. Food Chem. 2015, 173, 375-381. [CrossRef] [PubMed]

5. Fernandes, D.; Benianno, M.J.; Porte, C. Hepatic levels of metal and metallothioneins in two commercial fish species of the Northern Iberian shelf. Sci. Total Environ. 2008, 391, 159-167. [CrossRef]

6. Xiong, C.H.; Yao, C.P. Study on the adsorption of cadmium(II) from aqueous solution by D152 resin. J. Hazard. Mater. 2009, 166, 815-820. [CrossRef]

7. Yelebe, Z.R.; Yelebe, B.Z.; Samuel, R.J. Design of fixed bed column for the removal of metal contaminants from industrial wastewater. J. Eng. Appl. Sci. 2013, 5, 57-66.

8. Purkayastha, D.; Mishra, U.; Biswas, S. A comprehensive review on Cd(II) removal from aqueous solution. J. Water Process. Eng. 2014, 2, 105-128. [CrossRef]

9. Seki, H.; Okada, I.; Maruyama, H.; Kawabe, M.; Nakade, A. Removal of Cadmium from Squid Liver Method by Competitive Adsorption Method. Aquac. Sci. 2006, 54, 449-453.

10. Volesky, B. Sorption and Biosorption; BV Sorbex, Inc.: Saint-Lambert, QC, Canada, 2003.

11. Calderón, C.; Levio-Raiman, M.; Diez, M.C. Cadmium removal for marine food application: Comparative study of different adsorbents. Int. J. Environ. Sci. Technol. 2021, 1-14. [CrossRef]

12. Vijayalakshmi, K.; Sangeetha, K.; Sudha, P.N. Analysis of packed bed adsorption column with nanochitosan/sodium alginate/microcrystalline cellulose bead for copper (II) removal from aqueous solution. IOSR J. Pharm. 2017, 2, 69-78. 
13. Inglezakis, V.J.; Loizidou, M.D.; Grigoropoulou, H.P. Equilibrium and kinetic ion exchange studies of $\mathrm{Pb}^{2+}, \mathrm{Cr}^{3+}, \mathrm{Fe}^{3+}$ and $\mathrm{Cu}^{2+}$ on natural clinoptilolite. Water Res. 2002, 36, 2784-2792. [CrossRef]

14. Thomas, H.C. Heterogeneous Ion Exchange in a Flowing System. J. Am. Chem. Soc. 1944, 66, 1664-1666. [CrossRef]

15. Nazari, G.; Abolghasemi, H.; Esmaieli, M.; Sadeghi Pouya, E. Aqueous phase adsorption of cephalexin by walnut shell-based activated carbon: A fixed-bed column study. Appl. Surf. Sci. 2016, 375, 144-153. [CrossRef]

16. Saleh, A.D.; Sirhan, M.M.; Ismail, A.S. Study sorption and desorption of $\mathrm{Cd}^{+2}, \mathrm{~Pb}^{+2}$ ions by selected chelating resin to removal them from industrial and environmental wastes. Energy Rep. 2020, 6, 243-249. [CrossRef]

17. Taha, M.H.; Masoud, A.M.; Khawassek, Y.M.; Hussein, A.E.M.; Aly, H.F.; Guibal, E. Cadmium and iron removal from phosphoric acid using commercial resins for purification purpose. Environ. Sci. Pollut. Res. 2020, 27, 31278-31288. [CrossRef]

18. Perić, J.; Trgo, M.; Vukojević Medvidović, N. Removal of zinc, copper and lead by natural zeolite-A comparison of adsorption isotherms. Water Res. 2004, 38, 1893-1899. [CrossRef] [PubMed]

19. Elbadawy, H.A.; Abdel-Salam, A.H.; Khalil, T.E. The impact of an Amberlite XAD-16-based chelating resin for the removal of aqueous $\mathrm{Cd}(\mathrm{II})$ and $\mathrm{Pb}(\mathrm{II})$ ions. Microchem. J. 2021, 165, 106097. [CrossRef]

20. Lázaro, N.; López Sevilla, A.; Morales, S.; Marqués, A.M. Heavy metal biosorption by gellan gum gel beads. Water Res. 2003, 37, 2118-2126. [CrossRef]

21. Corami, A.; Mignardi, S.; Ferrini, V. Cadmium removal from single- and multi-metal $(\mathrm{Cd}+\mathrm{Pb}+\mathrm{Zn}+\mathrm{Cu})$ solutions by sorption on hydroxyapatite. J. Colloid Interface Sci. 2008, 317, 402-408. [CrossRef]

22. Vašák, M.; Meloni, G. Chemistry and biology of mammalian metallothioneins. J. Biol. Inorg. Chem. 2011, 16, 1067-1078. [CrossRef]

23. Levio-Raiman, M.; Briceño, G.; Schalchli, H.; Bornhardt, C.; Diez, M.C. Alternative treatment for metal ions removal from acid mine drainage using an organic biomixture as a low cost adsorbent. Environ. Technol. Innov. 2021, 24, 101853. [CrossRef] 